\title{
PERSEPSI DAN PENGETAHUAN MAHASISWA AKADEMI KEBIDANAN TAHIRAH AL BAETI TERHADAP GIZI REMAJA
}

\author{
Mudyawati Kamaruddin $^{1 *}$, Jusni ${ }^{1}$, Nurul Amalia Sari ${ }^{1}$ \\ ${ }^{1}$ Program Studi Kebidanan, Akademi Kebidanan Tahirah Al Baeti, Bulukumba, Sulawesi Selatan, \\ Indonesia
}

"Corresponding author: Telp: +628111520603, email: mudya07@gmail.com

\begin{abstract}
ABSTRAK
Remaja merupakan harapan bangsa, sehingga tak berlebihan jika dikatakan bahwa masa depan bangsa yang akan ditentukan pada keadaan remaja saat ini. Remaja yang sehat dan berkualitas menjadi perhatian yang besar bagi orang tua, praktisi pendidikan, dan remaja itu sendiri. Gizi remaja merupakan bagian dari sektor kesehatan yang penting dan menjadi perhatian besar dari pemerintah. Gizi yang baik merupakan pondasi bagi kesehatan masyarakat pengaruh gizi terhadap pertumbuhan, perkembangan, intelektual, dan produktivitas menunjukan besarnya peranan gizi bagi kehidupan manusia. Penelitian ini bertujuan untuk mengetahui persepsi dan pengetahuan Mahasiswa Akademi Kebidanan Tahirah Al Baeti Bulukumba tentang gizi remaja. Penelitian ini menggunakan metode penelitian berupa deskriftif untuk mengetahui persepsi dan pengetahuan mahasiwa di Akademi Kebidanan Tahirah Al Baeti (AKTABE) terhadap gizi remaja, data dalam penelitian ini diperoleh melalui tehnik observasi dengan menggunakan kuesioner dengan jumlah sampel 50 mahasiswa AKTABE sebagai responden dengan variabel penelitian persepsi dan pengetahuan. Berdasarkan data kuesioner diperoleh bahwa persepsi mahasiswa Akademi Kebidanan Tahirah Al Baeti Bulukumba tentang gizi remaja menunjukan $80 \%$ (40 responden) mempunyai persepsi baik, 20\% (10 responden) berpersepsi cukup, dan tidak ada mahasiswa yang berpersepsi kurang baik dan tidak baik. Sedangkan berdasarkan pengetahuan menunjukan bahwa dari 50 responden terdapat $88 \%$ (44 responden) berpengetahuan baik, dan berpengetahuan cukup baik terdapat $12 \%$ (6 responden). Pada penelitian ini tidak ada responden yang berpengetahuan kurang baik dan tidak baik.
\end{abstract}

Kata kunci : Persepsi, Pengetahuan, Gizi Remaja

\begin{abstract}
Teenagers are the prospect of a nation, it is no exaggeration to say that the future of the nation will be determined in the current state of adolescents. Healthy and quality of teenagers are of great concern to parents, educators, and adolescents themselves. Adolescent nutrition is an important part of the health sector and also a major concern of the government. Good nutrition is the foundation for public health, because the influence of nutrition on growth, development, intellectual, and productivity shows the great role of nutrition for human life. This study aims to determine the perceptions and knowledge of Midwifery Academy of Tahirah Al Baeti students about adolescent nutrition. This study used descriptive research methods to determine the perceptions and knowledge of Tahirah Al Baeti Midwifery Academy students on adolescent nutrition. The data in this study were obtained through observation techniques by using a questionnaire to 50 respondents. Research variables were perception and knowledge variables. Based on the questionnaire data, it was found that perception of the first and second level of Tahirah Al Baeti Midwifery Academy students were generally positive for adolescent nutrition (100\%). While, for knowledge it showed that there were $88 \%$ who had the good category and were $12 \%$ knowledgeable enough.
\end{abstract}

Keywords: Adolescent nutrition, Perception, Knowledge, Students 


\section{PENDAHULUAN}

Remaja adalah harapan bangsa, sehingga tak berlebihan jika dikatakan bahwa masa depan bangsa yang akan ditentukan pada keadaan remaja saat ini. Remaja yang sehat dan berkualitas menjadi perhatian serius bagi orang tua, praktisi pendidikan, ataupun remaja itu sendiri. Remaja mempunyai kebutuhan nutrisi yang spesial, karena pada saat tersebut terjadi pertumbuhan yang pesat dan terjadi perubahan kematangan fisiologis sehubungan dengan timbulnya pubertas. Pertumbuhan dan perkembangan yang terjadi dimasa remaja akan berpengaruh pada pengasupan dan konsumsi makanan (absorpsi) terutama zat gizi yang terkandung dalam makanan tersebut. Selain itu pengaruh hormon pertumbuhan dapat memicu pengasupan zat gizi yang lebih besar. ${ }^{1}$

Gizi merupakan bagian dari sektor kesehatan yang penting dan dapat perhatian serius dari pemerintah. Gizi yang baik merupakan pondasi bagi kesehatan masyarakat pengaruh gizi terhadap pertumbuhan, perkembangan, intelektual, dan produktivitas menunjukan besarnya peranan gizi bagi kehidupan manusia. Jika terjadi gangguan gizi baik gizi kurang maupun gizi lebih pertumbuhan tidak akan berlangsung optimal. ${ }^{2}$ Selain itu, gizi merupakan bagian yang cukup penting dalam mewujudkan sumber daya manusia yang berkualitas. Untuk mencapai keseimbangan konsumsi gizi pada setiap individu atau keluarga juga dipengaruhi banyak faktor seperti ekonomi, sosial budaya, kebiasaan, kesukaan, kondisi kesehatan termasuk juga pendidikan dan pengetahuan seputar masalah gizi. ${ }^{3}$ Masa remaja sangat penting diperhatikan karena merupakan masa transisi antara anak-anak dan dewasa. Gizi seimbang pada masa ini akan sangat menentukan kematangan mereka dimasa depan. Perhatian khusus perlu diberikan kepada remaja agar status gizi dan kesehatan yang optimal dapat dicapai. $^{4}$
Kebutuhan energi dan zat gizi diusia remaja ditujukan untuk desposisi jaringan tubuhnya. Total kebutuhan energi dan zat gizi remaja juga lebih tinggi dibandingkan dengan rentang usia sebelum dan sesudahnya. Apalagi masa remaja merupakan masa transisi penting dari pertumbuhan anak-anak menuju dewasa. Gizi seimbang pada masa tersebut akan sangat menentukan kematangan mereka dimasa depan. ${ }^{4}$ Intinya masa remaja adalah saat terjadinya perubahan-perubahan cepat, sehingga asupan zat gizi remaja harus diperhatikan benar agar mereka dapat tumbuh optimal. Apalagi dimasa ini aktifitas fisik remaja pada umumnya lebih banyak.Selain disibukkan dengan berbagai aktifitas disekolah, umumnya mereka mulai pula menekuni berbagai kegiatan seperti olahraga, kursus, dan lain-lain. Semua itu tentu akan menguras energi, yang berujung pada keharusan menyesuaikan dengan asupan zat gizi seimbang.

Salah satu penyebab timbulnya masalah gizi dan perubahan kebiasaan makanan pada remaja adalah pengetahuan gizi yang rendah dan terlihat pada kebiasaan makan yang salah. Permaesih (2003) menyatakan bahwa pengetahuan dan praktek gizi remaja yang rendah tercermin dari perilaku menyimpang dalam kebiasaan memilih makanan. ${ }^{5}$ Remaja yang memiliki pengetahuan gizi yang baik dewasa sebenarnya bisa diperbaiki saat remaja melalui pemberiaan pengetahuan dan kesadaran tentang kebiasaan makan dan gaya hidup yang sehat. ${ }^{6}$ Berdasarkan data yang diperoleh dari Dinas Kesehatan (Dinkes) Kabupaten Bulukumba tahun 2017 sebanyak 4.320 remaja yang mendapatkan tablet Ferrum (Fe). Akan tetapi Dinkes Bulukumba tidak mengukur status gizi remaja yang ada di kabupaten Bulukumba. $^{7}$

Berdasarkan pengambilan data awal terkait dengan tempat penelitian yaitu akan bertempat di Kampus Akademi Kebidanan Tahirah Al Baeti Bulukumba, pada tingkat I sebanyak 39 mahasiswa dan tingkat II adalah 24 mahasiswa. Berdasarkan hasil 
wawancara secara random terhadap mahasiswa tingkat I sebanyak 5 orang dan mahasiswa tingkat II sebanyak 5 mahasiswa, sehingga total mahasiswa yang diwawancarai sebanyak 10 mahasiswa. Didapatkan bahwa pengetahuan dan persepsi mereka mengenai gizi remaja masih kurang. Berdasarkan pengetahuannya, mereka masih kurang mengetahui tentang pengertian gizi remaja, dan asupan makanan apa saja yang dibutuhkan remaja agar gizinya tercukupi, sehingga mereka hanya mengonsumsi makanan yang memberikan kekenyangan tanpa melihat sisi gizi dari makanan tersebut. Sedangkan berdasarkan persepsinya, mereka masih menganggap bahwa gizi pada remaja tidak begitu perlu untuk diketahui, mereka beranggapan bahwa gizi hanya perlu untuk wanita usia subur (WUS) dan ibu hamil. Hal inilah yang menarik untuk dilakukan penelitian di Akademi Kebidanan Tahirah Al Baeti Bulukumba tentang persepsi dan pengetahuan mahasiswa terhadap gizi remaja. $^{8}$

\section{METODOLOGI}

\section{Lokasi dan Jenis Penelitian}

Penelitian ini dilakukan pada mahasiswa tingkat I dengan jumlah 39 mahasiswa dan tingkat II dengan jumlah 24 mahasiswa, dilaksanakan di Akademi Kebidanan Tahirah Al Baeti Bulukumba dengan metode Purposive Sampling untuk mendeskripsikan persepsi dan pengetahuan mahasiswa tentang gizi remaja.

\section{Populasi dan Sampel}

Populasi penelitian adalah mahasiswa tingkat I dan tingkat II yang belajar di Akademi Kebidanan Tahirah Al Baeti Bulukumba di Kabupaten Bulukumba. Sedangkan yang dijadikan sampel dalam penelitian ini adalah populasi yang memenuhi kriteria inklusi dengan jumlah 50 mahasiswa.

\section{Metode Pengumpulan Data}

Metode pengumpulan data dengan menggunakan data primer dimana peneliti melakukan pendataan langsung tentang identitas mahasiswa yang dijadikan responden penelitian. Identitas mahasiswa meliputi nama, tempat tanggal lahir, usia dan alamat dengan cara wawancara. Kemudian setiap responden diberikan lembar kuesioner sesuai dengan petunjuk yang berlaku.

\section{HASIL DAN PEMBAHASAN}

HASIL

Berdasarkan hasil distribusi frekuensi mahasiswa terhadap gizi remaja menunjukkan mahasiswa tingkat I dengan jumlah 39 mahasiswa dan tingkat II dengan jumlah 24 mahasiswa.

\section{a. Gambaran persepsi mahasiswa terhadap gizi remaja}

Distribusi persepsi mahasiswa terhadap gizi remaja pada mahasiswa tingkat I dan II Akademi Kebidanan Tahirah Al Baeti Bulukumba disajikan pada table 1 di bawah ini :

Tabel 1 Distribusi frekuensi responden berdasarkan persepsi mahasiswa tingkat I dan II terhadap gizi remaja di Akbid Tahirah Al Baeti (AKTABE)

\begin{tabular}{cccc}
\hline No. & Persepsi & Nilai & $\begin{array}{c}\text { Presentase } \\
\%\end{array}$ \\
\hline 1. & Positif & 50 & $100 \%$ \\
2. & Negatif & 0 & $0 \%$ \\
\hline & Total & 50 & 100 \\
\hline
\end{tabular}

Sumber: Data primer persepsi (Nurul AS., 2019)

Dari table 1 menunjukan bahwa dari 50 responden yang diteliti menunjukkan semua responden memiliki persepsi yang positif.

\section{b. Gambaran pengetahuan mahasiswa terhadap gizi remaja \\ Distribusi pengetahuan mahasiswa terhadap gizi remaja pada mahasiswa tingkat I dan II Akademi Kebidanan Tahirah Al Baeti Bulukumba disajikan pada table 2 di bawah ini :}


Tabel 2 Distribusi frekuensi responden berdasarkan pengetahuan mahasiswa tingkat I Dan II tentang gizi remaja di Akbid Tahirah Al Baeti (AKTABE)

\begin{tabular}{cccc}
\hline No. & Pengetahuan & Nilai & $\begin{array}{c}\text { Presentase } \\
\%\end{array}$ \\
\hline 1. & Baik & 44 & $88 \%$ \\
2. & Cukup baik & 6 & $12 \%$ \\
3. & Kurang baik & 0 & 0 \\
4. & Tidak baik & 0 & 0 \\
\hline & Total & 50 & 100
\end{tabular}

Sumber: Data primer pengetahuan (Nurul AS., 2019)

Dari table 2 di atas, hasil penelitian menunjukkan bahwa hampir semua mahasiswa Akademi Kebidanan Tahirah Al Baeti berpengetahuan baik tentang gizi remaja yaitu terdapat 44 mahasiswa (88\%), dan yang berpengetahuan cukup baik terdapat 6 mahasiswa (12\%). Tidak ada satupun mahasiswa yang berpengetahuan kurang baik dan tidak baik tentang gizi remaja.

\section{PEMBAHASAN}

\section{a. Pembahasan terhadap persepsi}

Dalam memberikan persepsi terhadap gizi remaja, masing-masing individu akan memberikan respon secara berbeda. Hal ini dikarenakan pandangan seseorang dipengaruhi oleh wawasan, pengalaman serta pengetahuannya terhadap suatu objek yang dihadapkan. Mahasiswa kesehatan, khususnya program kebidanan Akademi Kebidanan Tahirah Al Baeti Bulukumba yang mendapatkan materi tentang ilmu gizi pada semester awal perkuliahan sehingga tingkat I dan tingkat IImemiliki kesamaan dalam berpengetahun tentang materi gizi tersebut. Namun terdapat perbedaan antara tingkat I dan tingat II terkait pengalaman karena beberapa mahasiswa yang sudah menekuni praktek di luar kampus seperti Rumah Sakit, Puskesmas atau berinteraksi dengan komunitas di luar kampus, kemungkinan mempunyai wawasan, pengalaman bahkan pengetahuan yang berbeda dan lebih baik dibanding dengan mahasiswa yang masih berada ditingkat awal.

Hal tersebut juga dipertegas dengan hasil penelitian yang telah dilakukan ini, diperoleh semua mahasiswa persepsi positif tentang gizi remaja, dari tabel 1 menunjukan bahwa dari 50 responden (mahasiswa) yang diteliti semua responden memiliki persepsi yang positif dimana mahasiswa tingkat I sebanyak 26 orang dan tingkat II sebanyak 24 orang.

Menurut Rahmadani (2015), setiap orang mempunyai persepsi sendiri mengenai apa yang dipikirkan, dilihat, dan dirasakan. Hal tersebut sekaligus berarti bahwa persepsi menentukan apa yang akan diperbuat seseorang untuk memenuhi berbagai kepentingan baik untuk diri sendiri, keluarga, maupun lingkungan masyarakat tempat berinteraksi. Persepsi inilah yang membedakan seseorang dengan yang lain. Persepsi dihasilkan dari konkritasi pemikiran, kemudian melahirkan konsep atau ide yang berbeda-beda dari masing-masing orang meskipun obyek yang dilihat sama. Berdasarkan pernyataan tersebut sebaiknya mahasiswa mempunyai persepsi sendiri mengenai apa yang dipikirkan, dilihat, dan dirasakan terkait gizi remaja. ${ }^{9}$

\section{b. Pembahasan tentang pengetahuan}

Pengetahuan mahasiswa tentang gizi remaja merupakan informasi tentang gizi yang telah diproses dan diorganisasikan untuk memperoleh pemahaman, pembelajaran dan pengalaman yang terakumulasi sehingga dapat diaplikasikan ke dalam proses belajar tertentu. Peningkatan pengetahuan yang dimiliki oleh seseorang, khususnya mahasiswa berhubungan erat dengan usaha yang dilakukan dalam proses belajar, waktu yang ditempuh untuk proses pembelajaran mendapatkan pengetahuan dan banyaknya pengalaman yang diperoleh selama berinteraksi dengan pengetahuan tersebut.

Hal ini tidak menutup kemungkinan bahwa mahasiswa tingkat II Akademi Kebidanan Tahirah Al Baeti, merupakan 
mahasiswa yang telah banyak berinteraksi dengan pengalaman praktek selama beberapa kali dan interaksi dengan komunitas dibanding dengan mahasiswa yang masih tingkat awal (tingkat I).Dari hasil penelitian yang dilakukan, pengetahuan mahasiswa tentang gizi remaja didominasi oleh mahasiswa tingkat II dan beberapa mahasiswa tingkat I yang tergolong dalam $88 \%$ dimana tingkat I terdapat 19 mahasiswa dan tingkat II sebanyak 25yang berpengetahuan baik, selebihnya adalah $12 \%$, dimana 4 mahasiswa dari tingkat I dan 2 mahasiswa dari tingkat II yang berpengetahuan cukup baik.

Dari beberapa indikator pernyataan ternyata ada point yang di jawab salah yaitu pada point 8 yaitu pemenuhan gizi seperti energi dan protein lebih banyak dibutuhkan oleh remaja dibandingkan orang dewasa karena pada umumnya lebih banyak melakukan aktivitas fisik. Sedangkan pada indikator soal yang banyak menjawab benar terdapat pada poit 10 yaitu ekonomi merupakan salah satu faktor yang menyebakan tidak terpenuhinya asupan gizi pada remaja.

\section{KESIMPULAN}

Berdasarkan hasil penelitian terhadap 50 mahasiswa sebagai responden penelitian di kampus Akbid Tahirah Al Baeti Bulukumba terhadap persepsi dan pengetahuan mahasiswa tentang gizi remaja, maka kesimpulan yang diperoleh adalahpersepsi yang dimiliki mahasiswa tingkat I dan II adalahpositif dengan presentasi penyebarannya adalah $80 \%$ dari tingkat I sebanyak 26 mahasiswa dan $\begin{array}{llll}\text { tingkat II } & \text { sebanyak }\end{array}$ mahasiswa.Begitupun pengetahuan yang dimiliki mahasiswa tingkat I dan II tentang gizi remaja $88 \%$ dari tingkat I sebanyak 19 mahasiswa dan tingkat II sebanyak 25 mahasiswa yang berpengetahuan baik, dan $12 \%$ dari tingkat I sebanyak 4 mahasiswa dan tingkat II sebanyak 2 mahasiswa yang berpengetahuan cukup baik.

\section{DAFTAR PUSTAKA}

1. Aryani. 2012. kesehatan remaja problem dan solusinya.Salemba Medika. Jakarta

2. Syamsidar. 2014. Gambaran pengetahuan siswa kelas VII, VIII, dan XI tentang gizi seimbang di SMP Satap 2 Balandidi Kecamatan Kindang Kabupaten Bulukumba 2014.Di akses 16 November 2018.

3. Solikhah. 2011. Pengaruh buku saku gizi terhadap tingkat pengetahuan gizi pada anak, Kab. Yokyakarta.

4. Dedeh dkk. 2010. Sehat Dan Bugar Berkat Gizi Seimbang.PT Penerbit Sarana Bobo. Jakarta

5. Permaisih. 2003. Status Gizi Remaja dan Faktor-Faktor yang

Mempengaruhinya. http:digliblitbang Depkes.co.id/diakses pada tanggal 16 November 2018.

6. Emilia. 2009. Pengetahuan, sikap, dan praktek gizi pada remaja dan implikasinya pada sosialisasi perilaku hidup sehat.Bogor

7. Dinas Kesehatan Kabupaten Bulukumba. 2017. Pemberian Tablet Fe Pada Remaja

8. Word Health Organization (WHO). 2015. 'Adolescent Development: Topics at Glance', diunduh dari http://www.who,int/maternal_child_ad olescent/topics/adolescence/dev/en\#

9. Ramadhani Purba, Zhuhri. 2015. Rancangan Bangun Sistem Autotracking Antena Unidirectional Menggunakan Data GPS. Universitas Sumatra Utara. Medan 